\title{
Landform type mediates compositional change in a hurricane-disturbed sub- tropical forest
}

\author{
Robert L. Spicer ${ }^{1}$, Ariel E. Lugo ${ }^{2}$ and Nathan Ruhl ${ }^{1^{*}}$
}

\begin{abstract}
Background: Categorization of topographical features into landform type is a long-standing method for understanding physiographic patterns in the environment. Differences in forest composition between landform types are driven primarily by concurrent differences in soil composition and moisture, but also disturbance regime. Many studies have focused on the interaction between fire disturbance, succession, and landforms, but the effects of hurricane disturbance on compositional differences between landforms are poorly understood. In the study presented here, we assess compositional and structural differences between landform types in the tree community of a young sub-tropical forest that is frequently subjected to hurricanes. Specifically, we ask whether the tree community (1) changed structurally over the study period, (2) experienced compositional change over the study period, (3) is compositionally different between landform types, and (4) exhibits compositional change mediated by landform type.
\end{abstract}

Results: The tree community experienced significant structural change over the course of our study, but compositional change was only significant for some landforms.

Conclusion: Despite large-scale, intense, and frequent hurricane disturbance to our study system, compositional change in the tree community was localized and only significant for some landform types.

Keywords: Hurricane, Forest, Community, Composition, Change, Succession, Landform

\section{Background}

Topographic variation (the combination of elevation and orientation) introduces complexity to the spatial variation of a host of factors including light availability (Tateno and Takeda 2003), climate (Bader and Ruijten 2008), soil moisture (Foster 1988; Hunter and Parker 1993), drainage patterns (Nobre et al. 2011), soil depth, nutrient concentrations (Brubaker et al. 1993; Enoki et al. 1997; Schimel et al. 1985; Zak et al. 1991), and total soil nutrient accumulation (Scatena and Lugo 1995). Topographic variation, in association with climactic and geologic factors, creates physiographic patterns that invite typology (Grossman et al. 1999), so many ecological classification methods for considering

\footnotetext{
* Correspondence: Ruhl@Rowan.edu

'Department of Biological Science, Rowan University, Glassboro, NJ 08028, USA

Full list of author information is available at the end of the article
}

physiographic patterns relative to biota exist (reviewed by Sims and Uhlig 1992; Klijn and Udo de Haes 1994; Kent et al. 1997; Simensen et al. 2018). The common theme with all ecological classification tools is that they help us identify, manage, and appreciate patterns in the environment.

One commonly used ecological classification tool is categorization of terrestrial habitats by landform type. Landform type is in the "habitat" family of classification tools that focus on ecological classification according to the physical environment (drainage patterns and elevation in this case), which have been shown to be more repeatable than other classification methods (Hearn et al. 2011). Landform type is one of the older ecological classification tools, dating back to at least 1961 (Hills), and is often implemented as best suited to the system being studied. The combined topography/drainage pattern approach to ecological classification is powerful for its broad utility and transferability across 
habitat types but suffers from subjectivity due to a lack of strict guidelines or thresholds that define the operational units (Barnes et al. 1982; Fortin et al. 2000).

Differences in forest compositional change (successional trajectories) between landform types have been noted for some time (Host et al. 1987), and it is thought that these patterns in forests are driven primarily by concurrent differences in soil composition and moisture, but also disturbance regime (Barnes et al. 1998; White and Host 2008). Many studies have focused on the interaction between fire disturbance, succession, and landforms (e.g., Chu et al. 2017; Keeton and Franklin 2004), but few have addressed wind effects in the same context (Sinton et al. 2000) and less so in tropical latitudes. Hurricanes are the dominant vector of disturbance for many tropical and sub-tropical forests (Lugo 2008) and manifest as a combination of both wind and rain/flood disturbance, and the effects of hurricanes on successional differences between landform types are therefore poorly understood compared to other vectors of disturbance. Like fire disturbance, hurricane disturbance alters a forest community in both positive and negative ways (Lugo 2008) and the effects of disturbance interact with topography (Scatena and Lugo 1995).

It has been demonstrated that hurricane effects differ between landform types in sub-tropical forests (Bellingham 1991), but whether those effects translate into compositional change, succession, or differences in successional trajectory between landform types has not been assessed. Addressing this gap in our understanding of tropical and sub-tropical forests is important and timely because a change in intensity or frequency of hurricanes as a result of climate change (Emanuel and Sobel 2013) could have a profound influence on the structure, composition, and/or function of these forests. More generally, despite many studies taking a top-down (regional/local) perspective to succession, there is an unmet need for "bottom-up" studies that link physiographic characteristics, such as landforms, to succession (Nave et al. 2017) as a generalized process shared across many ecosystems. In the study presented here, we utilize an older dataset to assess the importance of landform type on compositional change in the tree community of a young sub-tropical forest that is frequently subjected to hurricanes. Specifically, we ask whether the tree community (1) changed structurally over the study period, (2) experienced compositional change over the study period, (3) is compositionally different between landform types, and (4) exhibits compositional change mediated by landform type.

\section{Materials and methods}

\section{Study site}

The Jardín Botánico and Bosque Estatal del Nuevo Milenio (JB-BN; Fig. 1) are urban moist secondary sub-tropical forest plots that together form part of the Ecological Corridor of San Juan. All plots were located on lands previously used as an agricultural experimentation station affiliated with the University of Puerto Rico and used for a variety of science and conservation-related agricultural activities. When this study started in 1997, the forest was about 60 years old (Despiau Batista 1997), making the forest about 68 years old at the conclusion of our study in 2005 (Lugo et al. 2005).

While our study site is frequently disturbed by hurricanes (Table 1), the intensity and severity of disturbance depends on the trajectory, strength, and orientation of the storm relative to the location of the study forest. Hurricane Georges struck Puerto Rico in 1998 (the year after we initiated this study) as a category three storm and caused widespread damage to infrastructure and agriculture as a result of extreme rainfall $(720 \mathrm{~mm})$, winds $(185 \mathrm{~km} / \mathrm{h})$, and storm surge ( $3.05 \mathrm{~m}$; Silva-Araya et al. 2018). Our study site was exposed to the strongest quadrat of hurricane Georges as it passed over the Island and hurricane Georges had the strongest visible effects of the nine hurricanes and storms in Table 1. In contrast, our site was exposed to the weakest quadrangle of hurricane Hugo, which had similar strength as Georges, but followed a trajectory north of Puerto Rico.

Storm Jeanne struck the island of Puerto Rico in 2004 (the year before the conclusion of our study) but did not have as strong an effect on the trees of JB-BN as Hurricane Georges did in 1998. Jeanne did produce significant rainfall over the $8 \mathrm{~h}$ it took to pass over the Island. The winds of hurricane Georges were four times more powerful than those of Jeanne because wind power is the cube of velocity. Hurricane Debby passed north of Puerto Rico, and its main effects on Puerto Rico were high rainfall with winds being less powerful because they originated on the weakest quadrangle of the hurricane. Hurricane Jose, passing north and east of Puerto Rico, and hurricane Lenny, passing south and east, were less powerful hurricanes, and despite being measurable at the San Juan Airport, their effects on JB-BN were minor.

\section{Field sampling}

Data for this study were originally collected as part of a descriptive study of JB-BN tree biodiversity by Despiau Batista (1997). The initial data collection occurred during the months of June and July 1997 and utilized ten random plots of $254 \mathrm{~m}^{2}$ for each of four landform types (40 plots total) on the same southwest aspect at an elevation of 15 to $65 \mathrm{~m}$ above mean sea level. Plot size was maintained across the study, but two sites were rectangular while the rest were circular (Fig. 1).

Simple landform types (slope, ridge, draw, riverine) were assigned by Despiau Batista (1997) a priori using USGS topographic maps and confirmed via ground-checking drainage patterns. Landform type was not recorded for a few sites, so the study presented here ultimately utilized 33 of the original 40 plots ( 8 ridge, 9 slope, 8 riverine, and 8 draw; Fig. 1; Appendix 1). Trees with a diameter at breast height (DBH) equal to or greater than $4 \mathrm{~cm}$ were recorded and 


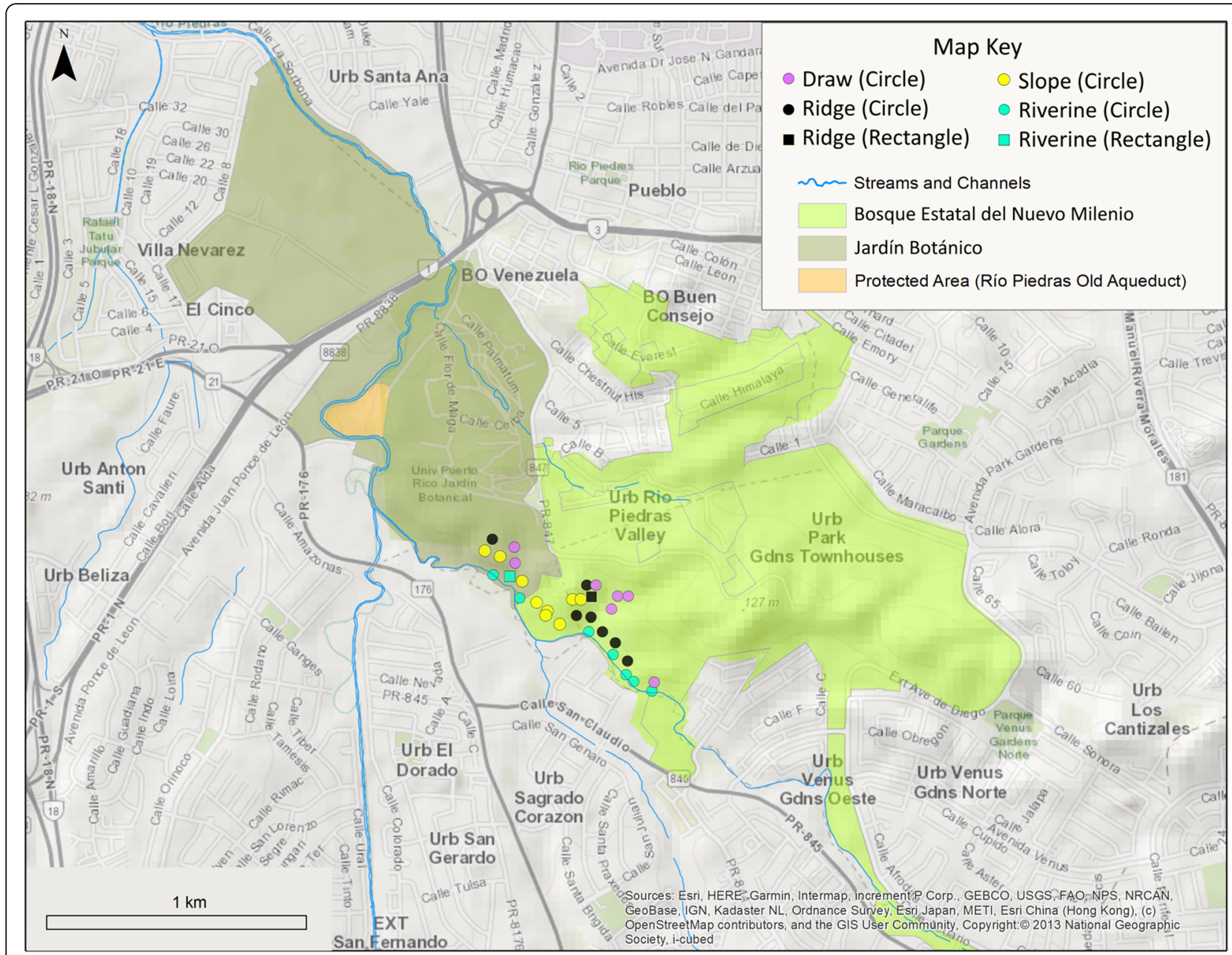

Fig. 1 Map of study plots within the Jardín Botánico and the Bosque Estatal del Nuevo Milenio, in Río Piedras Puerto Rico. Symbols indicate the shape of the sampling plot; colors indicate landform type: riverine (teal), slope (yellow), draw (purple), and ridge (black). Map was created using ArcGIS (ESRI)

identified to species (after Molina and Alemañy 1997), tree height was estimated using a clinometer, and trees were marked with aluminum tags for future identification. The plots were surveyed again in 2005 between the months of June and September by Lugo et al. (2005). Tagged trees were re-measured for $\mathrm{DBH}$ and height while new trees with $\mathrm{DBH} \geq 4 \mathrm{~cm}$ were given ID's and their $\mathrm{DBH}$ and height were recorded.

\section{Statistical methods}

Structural differences (DBH and height) were compared between landforms (within each study year) using Kruskal-

Table 1 Hurricanes and storms that struck JB-BN during our study (1997-2005) and for the 10 years prior to the study

\begin{tabular}{|c|c|c|c|c|c|}
\hline Year & Hurricane/Storm & Station & Sustain Surface Wind (knots) ${ }^{1}$ & Peak surface wind (knots) & Total Rainfall $(\mathrm{cm})$ \\
\hline 1989 & Hugo & San Juan (Carolina) Airport & 67 & 80 & 7.62 \\
\hline 1995 & Marilyn & San Juan (Carolina) Airport & 23 & 39 & 6.40 \\
\hline 1996 & Bertha & San Juan (Carolina) Airport & 42 & 52 & 3.96 \\
\hline 1996 & Hortense & San Juan (Carolina) Airport & 43 & 54 & 24.00 \\
\hline 1998 & Georges & San Juan (Carolina) Airport & 69 & 81 & 13.36 \\
\hline 1999 & Jose & San Juan (Carolina) Airport & 20 & 26 & 3.30 \\
\hline 1999 & Lenny & San Juan (Carolina) Airport & 29 & 34 & 6.38 \\
\hline 2000 & Debby & Rio de la Plata & Missing & Missing & 26.11 \\
\hline 2004 & Jeanne & San Juan (Carolina) Airport & 43 & 62 & 15.19 \\
\hline
\end{tabular}


Wallis tests with Steel-Dwass pair-wise contrasts and between years (1997 vs. 2005) using Wilcoxon tests (JMP 13) grouped by landform type. Some trees included in the PERMANOVA and NMDS procedures (below) were missing height measurements in both $1997(n=18)$ and $2005(n=11)$, so these trees were excluded ( $0.8 \%$ of pooled data) (Table 2$)$.

Whole-forest compositional change across years (1997 to 2005) was assessed via permutational multivariate analysis of variance (PERMANOVA; Adonis function, Bray-Curtis distance, Vegan package, $\mathrm{R}$ 3.4). The PERMANOVA method of comparing biodiversity patterns between sites is non-parametric (distribution-free) and in the nullhypothesis family of biodiversity measures (Anderson and Walsh 2013; Magurran 2004). PERMANOVA was also used in each of 1997 and 2005 to detect differences in biodiversity attributable to landform type, but in this case, we utilized pairwise contrasts as a post hoc test to detect differences between each landform type (pair-wise ADONIS, R 3.4, Arbizu 2019). Significant $p$ values in a PERMANOVA indicate a significant difference in a combination of centroid or spread of points in multivariate space, so nonmetric multi-dimensional scaling (NMDS; Vegan package, $\mathrm{mDS}$ function R 3.4) with factor fitting (envfit and ordiellipse functions, Vegan package, $\mathrm{R}$ 3.4) was utilized to visualize biodiversity differences due to landform type. Multivariate homogeneity for PERMANOVA factors (year and landform type) were assessed using the betadisper and permutest functions in the vegan package of $\mathrm{R}$ (3.4).

Compositional change from 1997 to 2005 by landform type was assessed via a test for concordance between NMDS ordinations (1997 vs. 2005) using symmetric Procrustes rotation (PROTEST function, vegan package, $\mathrm{R}$ 3.4). Residuals were extracted from the Procrustes rotation, normalized using a Box-Cox Y-transform (JMP 13), and compared between landform types using a one-way ANOVA with post hoc Tukey HSD test (JMP 13).

\section{Results}

Structural change between landform types and years

During 1997, the DBH of trees at riverine sites was significantly greater than those at ridge and slope sites and marginally greater than draw sites (Tables 3 and 4). The DBH of the average tree increased significantly from 1997 to
2005 at ridge and draw sites, increased marginally at riverine sites, and did not increase significantly at slope sites (Tables 3 and 5). During 2005, DBH was still significantly greater at riverine sites compared to other landform types, but $\mathrm{DBH}$ at slope sites was lesser than draw and ridge sites (Table 4). Tree height was significantly higher for draw sites than slope or ridge sites in both 1997 and 2005 (Tables 3 and 4), but the mean tree height decreased significantly across all sites from 1997 to 2005 (Tables 3 and 5). The number of stems declined from 1997 to 2005 for all landform types (20.55\% across the whole forest), but the decline in stems was more severe at ridge and slope sites $($ ridge $=34.47 \%$, slope $=28.08 \%$; Table 3 ).

\section{Whole-forest compositional change from 1997 to 2005}

A factorial PERMANOVA of the pooled data was not possible due to heterogeneous dispersions between landform types (permutest: $F_{3,62}=3.6073, p=0.03$ ) and unequal samples sizes between groups. A single factor PERMANOVA between years (1997 and 2005) indicated that there was no significant compositional change in the tree community between sampling periods $\left(F_{1,65}=0.3108, R^{2}=\right.$ $0.0048, p=0.983)$.

\section{Compositional differences between landforms in 1997 and 2005}

PERMANOVA of both the 1997 and 2005 forest communities (separately) indicated a significant effect due to landform type (1997: $F_{3,29}=2.617, R^{2}=0.213, p<0.001 ; 2005$ : $\left.F_{3,29}=3.003, R^{2}=0.237, p<0.001\right)$. The NMDS ordinations with landform factor fitting for 1997 (stress $=0.182$ in two dimensions, $r^{2}=0.4113, p=0.001$, Fig. 2a) and 2005 (stress $=0.167, r^{2}=0.3962, p=0.001$, Fig. $2 \mathrm{~b}$ ) also indicated a significant difference in biodiversity between landform types in both years. Pairwise PERMANOVA indicated that riverine sites were significantly different than slope and ridge sites in both 1997 and 2005 (Table 2).

\section{Compositional change by landform type from 1997 to 2005} The landform centroids for 1997 and 2005 were similar in size, shape, and orientation but were not identical, suggesting the presence of underlying differences in

Table 2 Pairwise PERMANOVA (ADONIS) results for between-landform differences in species diversity

\begin{tabular}{lllllll}
\hline & 1997 & & & 2005 & \\
\cline { 2 - 6 } Pairwise PERMANOVA & $F_{1}$ & $R^{2}$ & Adjusted $p$ & $F_{1}$ & $R^{2}$ & Adjusted $p$ \\
\hline Draw vs. ridge & 2.738 & 0.164 & 0.066 & 2.848 & 0.169 & 0.078 \\
Draw vs. riverine & 1.241 & 0.081 & 1.000 & 1.771 & 0.112 & 0.594 \\
Draw vs. slope & 1.886 & 0.112 & 0.246 & 0.482 & 0.142 & 0.090 \\
Ridge vs. riverine & 4.666 & 0.250 & 0.006 & 1.175 & 0.278 & 0.073 \\
Ridge vs. slope & 1.309 & 0.080 & 1.000 & 5.019 & 0.251 & 1.000 \\
Riverine vs. slope & 4.196 & 0.219 & 0.012 & 0.006 \\
\hline
\end{tabular}


Table 3 Descriptive statistics for forest structure metrics by landform type in 1997 and 2005

\begin{tabular}{|c|c|c|c|c|c|c|c|}
\hline Variable & Year & Statistic & Draw & Ridge & Riverine & Slope & Whole forest \\
\hline \multirow[t]{6}{*}{$\mathrm{DBH}(\mathrm{cm})$} & 1997 & Mean & 11.66 & 9.81 & 14.45 & 10.24 & 11.06 \\
\hline & & SD & 10.72 & 7.47 & 12.67 & 8.49 & 9.57 \\
\hline & & $n$ & 319 & 671 & 335 & 593 & 1918 \\
\hline & 2005 & Mean & 11.96 & 10.69 & 15.18 & 10.26 & 11.70 \\
\hline & & SD & 9.57 & 7.74 & 12.70 & 9.10 & 9.80 \\
\hline & & $n$ & 312 & 499 & 317 & 463 & 1591 \\
\hline \multirow[t]{6}{*}{ Height (m) } & 1997 & Mean & 10.00 & 8.59 & 9.70 & 8.31 & 8.93 \\
\hline & & SD & 4.70 & 3.54 & 5.45 & 3.62 & 4.21 \\
\hline & & $n$ & 317 & 669 & 333 & 582 & 1901 \\
\hline & 2005 & Mean & 8.00 & 7.24 & 7.42 & 7.52 & 7.50 \\
\hline & & SD & 2.93 & 2.62 & 2.79 & 3.58 & 3.03 \\
\hline & & $n$ & 311 & 499 & 317 & 453 & 1580 \\
\hline \multirow[t]{3}{*}{ Tree abundance } & 1997 & $n$ & 319 & 671 & 335 & 593 & 1918 \\
\hline & 2005 & $n$ & 312 & 499 & 317 & 463 & 1591 \\
\hline & & $\%$ Change & -2.24 & -34.47 & -5.68 & -28.08 & -20.55 \\
\hline
\end{tabular}

Sample size is lower for height because of missing data points

biodiversity over the course of the study related to landform type. Procrustes rotation indicated a high degree of concordance between sampling periods $\left(m^{2}=0.057, r=\right.$ $0.97, p=0.001)$. Procrustes residuals differed significantly between landform types (Fig. 3; one-way ANOVA: DF = $3, F_{3,29}=3.258, R^{2}=0.252, p=0.036$ ), and post hoc tests indicated that residuals for riverine sites were significantly lower than for ridge $(p=0.013)$ and draw $(p=0.011)$ sites. Species centroids relative to landform ellipses are given in Appendix 2; species codes are defined in Appendix 3.

\section{Discussion}

Over the 8-year period of our study, JB-BN was structurally altered by hurricane disturbances, but the wholeforest composition of the tree community did not change significantly. Whole-forest differences in the tree community over time were not significant, but there were significant differences in the tree community over time attributable to landform type, suggesting differences in succession between landform types. Successional change in forests is classically considered to be a function of soil depth and acute disturbance events (e.g., fire), but succession is a complex phenomenon operating at multiple scales in space-time (Breugel et al. 2019) and can occur without a predictable trajectory (Chazdon et al. 2007), which is how we consider succession here. Also, unlike successions initiated by fires or clearcutting that homogeneously reset the system to early stages, compositional change after a hurricane resets stands to earlier stages depending on the exposure of the landform to prevailing winds and the effects of winds on trees.

Structural change to the forest was detected for both tree height (all sites) and DBH (except at slope sites).

Table 4 Statistical tests comparing forest structural metrics between landform types

\begin{tabular}{|c|c|c|c|c|c|c|c|c|}
\hline \multirow[b]{2}{*}{ Kruskal-Wallis $^{1}$} & \multicolumn{2}{|c|}{1997 DBH } & \multicolumn{2}{|c|}{$2005 \mathrm{DBH}$} & \multicolumn{2}{|c|}{1997 height } & \multicolumn{2}{|c|}{2005 height } \\
\hline & $x^{2}$ & $p$ & $x^{2}$ & $p$ & $x^{2}$ & $p$ & $x^{2}$ & $p$ \\
\hline Between landforms & 26.924 & $<0.001$ & 62.538 & $<0.001$ & 36.152 & $<0.001$ & 24.458 & $<0.001$ \\
\hline Steel-Dwass test & $Z$ & $p$ & $Z$ & $p$ & $Z$ & $p$ & $Z$ & $p$ \\
\hline Riverine-slope & 4.519 & $<0.001$ & 7.419 & $<0.001$ & 2.162 & 0.134 & 1.511 & 0.431 \\
\hline Riverine-draw & 2.553 & 0.052 & 2.959 & 0.016 & -2.462 & 0.066 & -2.480 & 0.063 \\
\hline Riverine_ridge & 4.793 & $<0.001$ & 4.764 & $<0.001$ & 0.741 & 0.881 & 0.984 & 0.759 \\
\hline Slope-draw & -1.549 & 0.408 & -4.539 & $<0.001$ & -6.047 & $<0.001$ & -4.773 & $<0.001$ \\
\hline Slope-ridge & 0.180 & 0.998 & -3.965 & $<0.001$ & -2.369 & 0.083 & -1.080 & 0.702 \\
\hline Draw_ridge & 1.756 & 0.295 & 1.400 & 0.499 & 4.563 & $<0.001$ & 4.140 & $<0.001$ \\
\hline
\end{tabular}

Positive $Z$-scores indicate the mean of the first group (2005) is larger than the mean of the second group (1997) and vice versa for negative scores ${ }^{1} \mathrm{DF}=3$ 
Table 5 Statistical tests comparing forest structural metrics between years

\begin{tabular}{|c|c|c|c|c|}
\hline \multirow[b]{2}{*}{ Kruskal-Wallis $^{1}$} & \multicolumn{2}{|c|}{ DBH (cm) 2005-1997 } & \multicolumn{2}{|c|}{ Height $(\mathrm{m})$ 2005-1997 } \\
\hline & $x^{2}$ & $p$ & $x^{2}$ & $p$ \\
\hline Between years & 14.122 & $<0.001$ & 133.283 & $<0.001$ \\
\hline Steel-Dwass test & $Z$ & $p$ & $Z$ & $p$ \\
\hline Draw & 2.036 & 0.042 & -5.933 & $<0.001$ \\
\hline Ridge & 3.472 & $<0.001$ & -8.028 & $<0.001$ \\
\hline Riverine & 1.915 & 0.056 & -4.419 & $<0.001$ \\
\hline Slope & 0.797 & 0.425 & -5.928 & $<0.001$ \\
\hline
\end{tabular}

Positive Z-scores indicate the mean of the first group (2005) is larger than the mean of the second group (1997) and vice versa for negative scores

${ }^{1} \mathrm{DF}=1$

Wind power was likely responsible for the reduction in tree height via selective effects on canopy structure (Brokaw and Grear 1991; Uriarte et al. 2019). The increase in tree DBH reflects positive conditions for tree growth after the hurricane due to moisture availability, soil fertility, and light/space availability. Thus, the hurricane disturbances that affected our study site had positive (tree diameter change), negative (reduction in tree height and number of stems), and neutral effects (no overall compositional change) on the forest. It is important to note that while hurricane disturbance has an obvious and negative effect on tree mortality (Uriarte et al. 2019) and societal infrastructure, hurricanes can also have a positive effect on forests by opening canopy gaps (Brokaw 1985), which stimulate growth and productivity, increasing structural complexity (Xi et al. 2019), and redistributing soil nutrients (Gutiérrez del Arroyo and Silver 2018).
At JB-BN, tree community composition changed more at ridge and draw sites than riverine and slope sites. Normally, ridges and slopes have greater species richness than valleys (Scatena and Lugo 1995), which partially explains our results. One might expect that stands with a higher number of species are more likely to experience a change in biodiversity when disturbed compared to stands with fewer species because low diversity stands have species with greater dominance that are less likely to be lost while species in diverse stands are less dominant and have higher probability of not overcoming the disturbance. Also, slope and riverine locations are at lower elevations relative to draw and ridge sites and therefore less exposed to winds, but riverine locations are more likely to experience disturbance from flooding, which slows microbial decomposition and tree growth (Silver et al. 1999).

Differences in community composition between landform types were greatest for ridge and draw sites, but the
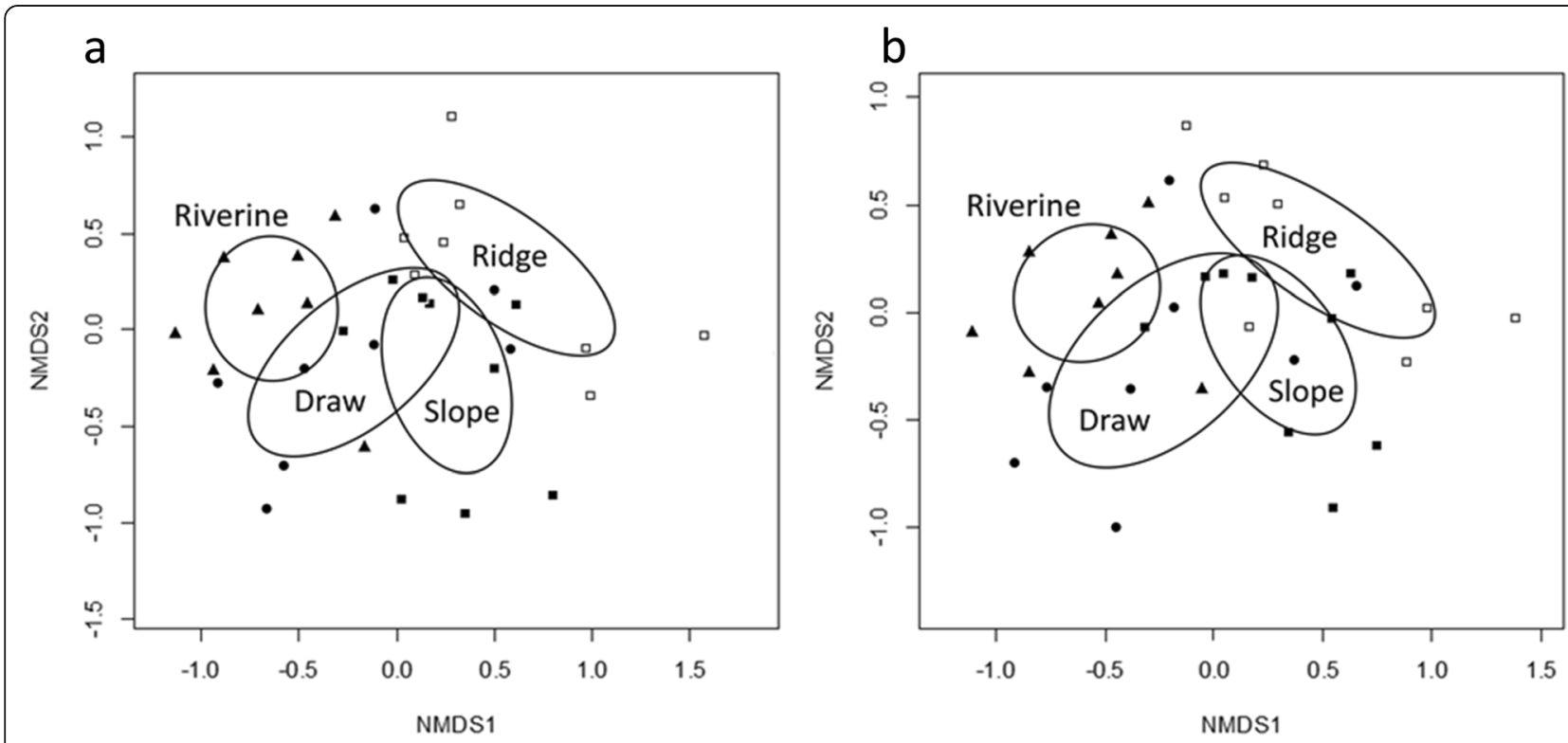

Fig. 2 NMDS ordinations of the forest tree biodiversity in 1997 (a) and 2005 (b) with factor fit of landform type. Riverine sites = triangles, draw sites $=$ circles, slope sites $=$ closed squares, ridge sites $=$ open squares 


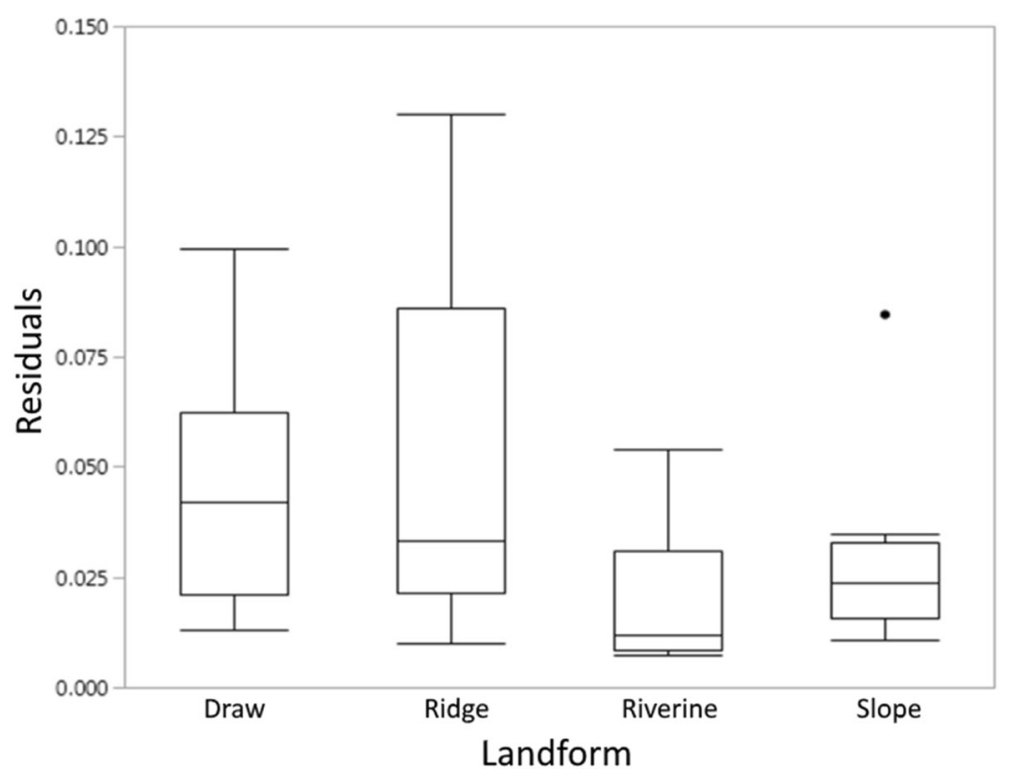

Fig. 3 Raw (non-normalized) Procrustes residuals by landform type from a Procrustes rotation of NMDS ordinations for each year shown in Fig. 2

reduction in the number of trees between 1997 and 2005 was greatest for ridge and slope sites. There appears to be a difference in mortality between landform types that is poorly aligned with successional change in our study system, an observation that we feel is most likely attributable to the young age (68 years) of the forest we studied. Young forests have lower resistance to successional change than older/mature forests, and so, the successional trajectory and rate of change in young forests (such as ours) may differ from those of similar older forests (such as that studied by Heartsill Scalley et al. 2010).

The compositional change that we measured at JB-BN, as in other studies of succession, are the result of biotic interactions and environmental heterogeneity (Boose et al. 2004; Uriarte et al. 2012; Hogan et al. 2016). Successional dynamics that are not significant at one spatial scale (whole forest) can become significant at smaller spatial scales (landform type) because these scales are ecologically relevant to the disturbance (as in this study and that of Mollot et al. 2008) or biotic interactions. These results, while both informative and intriguing, need to be interpreted with the knowledge that the disturbance regime at JB-BN is shaped by more than just frequent hurricanes. Prior to European colonization, Puerto Rico was $100 \%$ forested (Little et al. 1974), but by the late 1940 s, only $6 \%$ of the island remained forested, and only $1 \%$ of the primary forest remained (Lugo 2004; Roberts 1942). The forest at JB-BN is a relatively young forest and may respond differently to hurricane disturbance than an older forest. Likewise, disturbance via humans and hurricanes (Beard et al. 2005; Boose et al.
1994), as well as the effects of competition, is unlikely to be equally distributed across species (Batista and Platt 2003; Zimmerman et al. 1994) or the landscape (Comita et al. 2010).

\section{Conclusion}

Collectively, our results suggest a complicated interaction between landform type and hurricane disturbance mediates successional change and ecosystem dynamics/function in JB-BN. Despite large-scale, intense, and frequent disturbance to our study system, compositional change in the tree community was localized and only significant for some landform types. In the context of a change in hurricane intensity or frequency due to global warming, our results suggest that the effects may be differentially spread across forest communities. It is our view that landform classification is most useful for studies that seek to identify generalizable patterns that might also occur in other ecosystem types composed of differing species groups (e.g., succession in a boreal forest vs. a sub-tropical forest vs. a grassland) than to compare related sets of ecosystems composed of similar species groups (e.g., succession in a subtropical forest vs. another sub-tropical forest) unless such studies employ strictly defined typology. In our study, we utilize a very basic landform classification scheme that can be scaled and generalized to many habitat types. The generalizable characteristics of the landform typology make it useful for ecological classification efforts based on functional classes (nonphylogenetic groupings; Duckworth et al. 2000), studies of primary succession (e.g., McKenna et al. 2019), and "bottom-up" studies of succession. 


\section{Appendix 1}

Table 6 Sampling locations by sampling method and landform type

\begin{tabular}{|c|c|c|c|c|}
\hline Site ID & Latitude & Longitude & Plot shape $^{1}$ & Landform type \\
\hline 2 & $18^{\circ} 23^{\prime} 05.20^{\prime \prime} \mathrm{N}$ & $66^{\circ} 03^{\prime} 16.10^{\prime \prime} \mathrm{E}$ & Circular & Ridge \\
\hline 3 & $18^{\circ} 23^{\prime} 03.70^{\prime \prime} \mathrm{N}$ & $66^{\circ} 03^{\prime} 17.10^{\prime \prime} \mathrm{W}$ & Circular & Slope \\
\hline 4 & $18^{\circ} 23^{\prime} 03.00^{\prime \prime} \mathrm{N}$ & $66^{\circ} 03^{\prime} 15.10^{\prime \prime} \mathrm{W}$ & Circular & Slope \\
\hline 6 & $18^{\circ} 23^{\prime} 00.70^{\prime \prime} \mathrm{N}$ & $66^{\circ} 03^{\prime} 16.00^{\prime \prime} \mathrm{W}$ & Circular & Riverine \\
\hline 7 & $18^{\circ} 23^{\prime} 00.50^{\prime \prime} \mathrm{N}$ & $66^{\circ} 03^{\prime} 13.80^{\prime \prime} \mathrm{W}$ & Rectangular & Riverine \\
\hline 8 & $18^{\circ} 23^{\prime} 04.20^{\prime \prime} \mathrm{N}$ & $66^{\circ} 03^{\prime} 13.20^{\prime \prime} \mathrm{W}$ & Circular & Draw \\
\hline 9 & $18^{\circ} 23^{\prime} 02.20^{\prime \prime} \mathrm{N}$ & $66^{\circ} 03^{\prime} 13.10^{\prime \prime} \mathrm{W}$ & Circular & Draw \\
\hline $10^{2}$ & $18^{\circ} 22^{\prime} 57.80^{\prime \prime} \mathrm{N}$ & $66^{\circ} 03^{\prime} 12.50^{\prime \prime} \mathrm{W}$ & Circular & Riverine \\
\hline 11 & $18^{\circ} 22^{\prime} 59.90^{\prime \prime} \mathrm{N}$ & $66^{\circ} 03^{\prime} 12.20^{\prime \prime} \mathrm{W}$ & Circular & Slope \\
\hline 13 & $18^{\circ} 22^{\prime} 57.20^{\prime \prime} \mathrm{N}$ & $66^{\circ} 03^{\prime} 10.30^{\prime \prime} \mathrm{W}$ & Circular & Slope \\
\hline 14 & $18^{\circ} 22^{\prime} 56.10^{\prime \prime} \mathrm{N}$ & $66^{\circ} 03^{\prime} 08.90^{\prime \prime} \mathrm{W}$ & Circular & Slope \\
\hline 15 & $18^{\circ} 22^{\prime} 55.60^{\prime \prime} \mathrm{N}$ & $66^{\circ} 03^{\prime} 09.10^{\prime \prime} \mathrm{W}$ & Circular & Slope \\
\hline 16 & $18^{\circ} 22^{\prime} 54.50^{\prime \prime} \mathrm{N}$ & $66^{\circ} 03^{\prime} 07.30^{\prime \prime} \mathrm{W}$ & Circular & Slope \\
\hline 17 & $18^{\circ} 22^{\prime} 57.60^{\prime \prime} \mathrm{N}$ & $66^{\circ} 03^{\prime} 05.60^{\prime \prime} \mathrm{W}$ & Circular & Slope \\
\hline 18 & $18^{\circ} 22^{\prime} 57.60^{\prime \prime} \mathrm{N}$ & $66^{\circ} 03^{\prime} 04.50^{\prime \prime} \mathrm{W}$ & Circular & Slope \\
\hline 19 & $18^{\circ} 22^{\prime} 59.40^{\prime \prime} \mathrm{N}$ & $66^{\circ} 03^{\prime} 03.70^{\prime \prime} \mathrm{W}$ & Circular & Ridge \\
\hline 21 & $18^{\circ} 22^{\prime} 55.60^{\prime \prime} \mathrm{N}$ & $66^{\circ} 03^{\prime} 05.10^{\prime \prime} \mathrm{W}$ & Circular & Ridge \\
\hline 22 & $18^{\circ} 22^{\prime} 59.40^{\prime \prime} \mathrm{N}$ & $66^{\circ} 03^{\prime} 02.50^{\prime \prime} \mathrm{W}$ & Circular & Draw \\
\hline 23 & $18^{\circ} 23^{\prime} 00.90^{\prime \prime} \mathrm{N}$ & $66^{\circ} 03^{\prime} 01.00^{\prime \prime} \mathrm{W}$ & Circular & Draw \\
\hline 24 & $18^{\circ} 22^{\prime} 58.00^{\prime \prime} \mathrm{N}$ & $66^{\circ} 02^{\prime} 59.70^{\prime \prime} \mathrm{W}$ & Circular & Draw \\
\hline 25 & $18^{\circ} 22^{\prime} 56.40^{\prime \prime} \mathrm{N}$ & $66^{\circ} 03^{\prime} 00.50^{\prime \prime} \mathrm{W}$ & Circular & Draw \\
\hline 26 & $18^{\circ} 22^{\prime} 57.90^{\prime \prime} \mathrm{N}$ & $66^{\circ} 03^{\prime} 03.10^{\prime \prime} \mathrm{W}$ & Rectangular & Ridge \\
\hline 27 & $18^{\circ} 22^{\prime} 55.40^{\prime \prime} \mathrm{N}$ & $66^{\circ} 03^{\prime} 03.20^{\prime \prime} \mathrm{W}$ & Circular & Ridge \\
\hline 28 & $18^{\circ} 22^{\prime} 53.60^{\prime \prime} \mathrm{N}$ & $66^{\circ} 03^{\prime} 03.50^{\prime \prime} \mathrm{W}$ & Circular & Riverine \\
\hline 29 & $18^{\circ} 22^{\prime} 53.60^{\prime \prime} \mathrm{N}$ & $66^{\circ} 03^{\prime} 01.70^{\prime \prime} \mathrm{W}$ & Circular & Ridge \\
\hline 31 & $18^{\circ} 22^{\prime} 52.20^{\prime \prime} \mathrm{N}$ & $66^{\circ} 03^{\prime} 00.00^{\prime \prime} \mathrm{W}$ & Circular & Ridge \\
\hline 32 & $18^{\circ} 22^{\prime} 50.70^{\prime \prime} \mathrm{N}$ & $66^{\circ} 03^{\prime} 00.30^{\prime \prime} \mathrm{W}$ & Circular & Riverine \\
\hline 33 & $18^{\circ} 22^{\prime} 58.00^{\prime \prime} \mathrm{N}$ & $66^{\circ} 02^{\prime} 58.30^{\prime \prime} \mathrm{W}$ & Circular & Draw \\
\hline 34 & $18^{\circ} 22^{\prime} 48.20^{\prime \prime} \mathrm{N}$ & $66^{\circ} 02^{\prime} 58.60^{\prime \prime} \mathrm{W}$ & Circular & Riverine \\
\hline 35 & $18^{\circ} 22^{\prime} 47.30^{\prime \prime} \mathrm{N}$ & $66^{\circ} 02^{\prime} 57.60^{\prime \prime} \mathrm{W}$ & Circular & Riverine \\
\hline 36 & $18^{\circ} 22^{\prime} 49.90^{\prime \prime} \mathrm{N}$ & $66^{\circ} 02^{\prime} 58.40^{\prime \prime} \mathrm{W}$ & Circular & Ridge \\
\hline 37 & $18^{\circ} 22^{\prime} 46.10^{\prime \prime} \mathrm{N}$ & $66^{\circ} 02^{\prime} 55.20^{\prime \prime} \mathrm{W}$ & Circular & Riverine \\
\hline 38 & $18^{\circ} 22^{\prime} 47.20^{\prime \prime} \mathrm{N}$ & $66^{\circ} 02^{\prime} 54.90^{\prime \prime} \mathrm{W}$ & Circular & Draw \\
\hline
\end{tabular}

${ }^{1}$ All sites were $254 \mathrm{~m}^{2}$ (circular $=$ radius of $9 \mathrm{~m}$; rectangular $=$ sides of $10 \mathrm{~m}$ and $25.4 \mathrm{~m}$ )

${ }^{2}$ Coordinates are approximate for this site 


\section{Appendix 2}
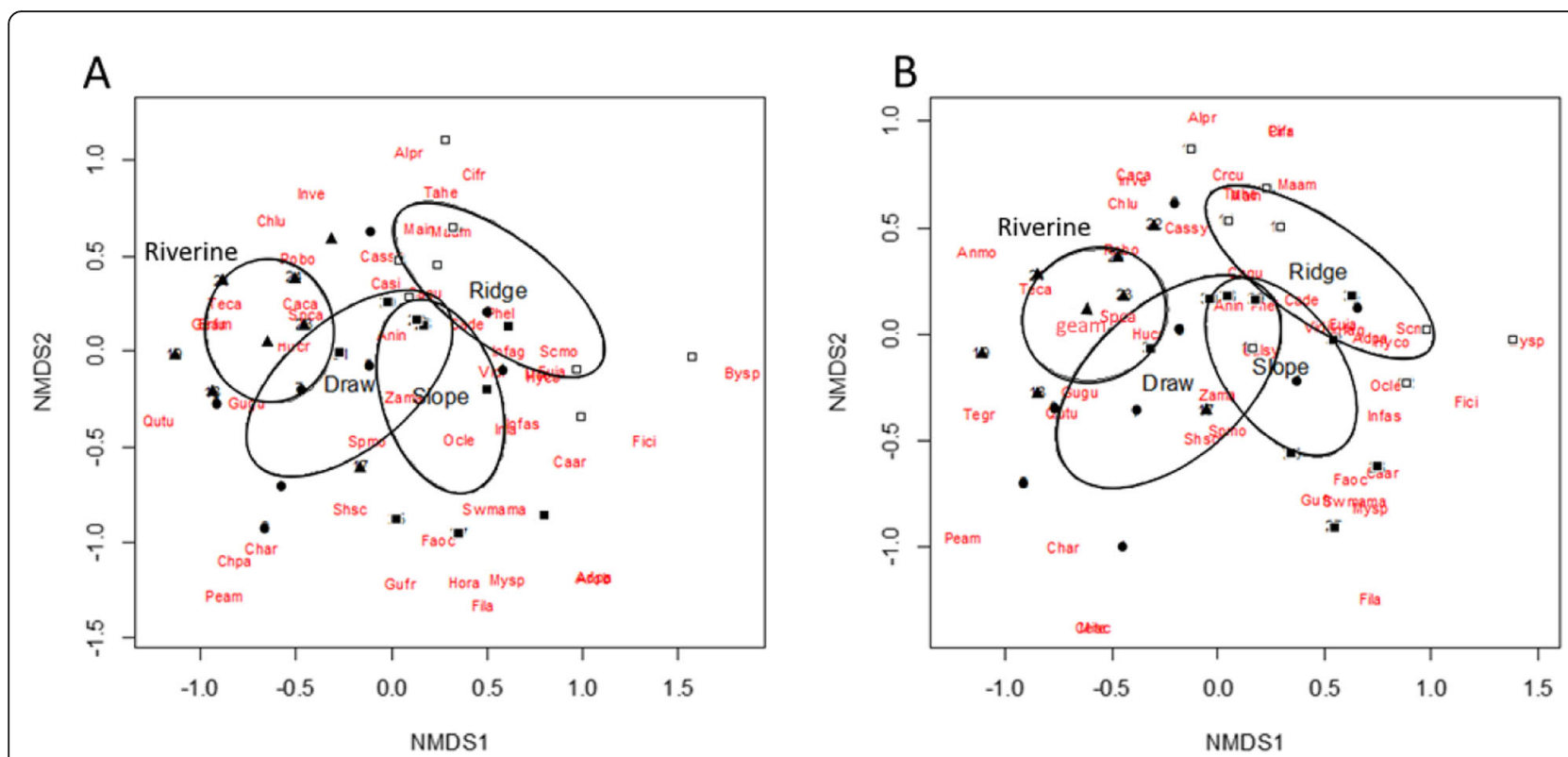

Fig. 4. NMDS ordinations of the forest tree biodiversity in 1997 (A) and 2005 (B) with factor fit of landform type showing species centroids. Riverine sites = triangles, draw sites = circles, slope sites = closed squares, ridge sites = open squares. Species codes are defined in Appendix 3. 


\section{Appendix 3}

Table 7 Species found in JB-BN with species codes used in the Appendix 1 NMDS ordinations and found in Appendix G of the Forest Inventory and Analysis (FIA) user guide (https://www.fia.fs.fed.us/library/database-documentation/historic/ver6/FIADB_User_ Guide_P2_6-1-1_final.pdf). For all species, SPGRPCD $=54$ and MAJGRP $=3$

\begin{tabular}{|c|c|c|}
\hline Species & NMDS species code & Forest service species code \# \\
\hline Acrocomia media & ACME & 6023 \\
\hline Adenanthera pavonina & ADPA & 6028 \\
\hline Albizia procera & ALPR & 6060 \\
\hline Andira inermis & ANIN & 6114 \\
\hline Annona montana & ANMO & 6127 \\
\hline Annona muricate & ANMU & 6218 \\
\hline Annona reticulata & ANRE & 6129 \\
\hline Ardisia obovate & $A R O B$ & 6164 \\
\hline Areca catechu & ARCA & 6167 \\
\hline Artocarpus heterophyllus & ARHE & 6173 \\
\hline Schefflera actinophylla & Brac & O888 \\
\hline Byrsonima spicata & BYSP & 6313 \\
\hline Callistemon citrinus & $\mathrm{CACl}$ & 6328 \\
\hline Calophyllum calaba & CACA & \\
\hline Calyptranthes sintenisii & CASI & 6356 \\
\hline Calyptranthes sylvestris & CASY & \\
\hline Cananga odorata & CAOD & 6370 \\
\hline Casearia arborea & CAAR & 6403 \\
\hline Casearia decandra & CADE & 6406 \\
\hline Casearia guianensis & CAGU & 6407 \\
\hline Casearia sylvestris & CASSY & 6410 \\
\hline Cassia fistula & CAFI & 6415 \\
\hline Cassia javanica & CAJA & 6418 \\
\hline Cecropia sceveriana & CESC & \\
\hline Cecropia schreberiana & CESH & 6443 \\
\hline Ceiba pentandra & CEPE & 6449 \\
\hline Dypsis lutescens & CHLU & 6966 \\
\hline Chrysophyllum argenteum & CHAR & 6539 \\
\hline Chrysophyllum cainito & $\mathrm{CHCA}$ & 6541 \\
\hline Chrysophyllum pauciflorum & CHPA & 6543 \\
\hline Citharexylum fruticosum & CIFR & O859 \\
\hline Coccoloba uvifera & COUV & 6670 \\
\hline Cocos nucifera & CONU & O908 \\
\hline Cordia sebestens & COSE & \\
\hline Crescentia cujete & CRCU & 6761 \\
\hline Cupania americana & CUAM & 6790 \\
\hline Delonix regia & DERE & 6883 \\
\hline Erytrhrina fusca & ERFU & \\
\hline Eucalyptus robusta & EURO & O514 \\
\hline Syzygium jambos & EUJA & 8701 \\
\hline Faramea occidentalis & FAOC & 7146 \\
\hline
\end{tabular}


Table 7 Species found in JB-BN with species codes used in the Appendix 1 NMDS ordinations and found in Appendix G of the Forest Inventory and Analysis (FIA) user guide (https://www.fia.fs.fed.us/library/database-documentation/historic/ver6/FIADB_User_ Guide_P2_6-1-1_final.pdf). For all species, SPGRPCD $=54$ and MAJGRP $=3$ (Continued)

\begin{tabular}{|c|c|c|}
\hline Species & NMDS species code & Forest service species code \# \\
\hline Ficus benjamina & FIBE & 7150 \\
\hline Ficus citrifolia & $\mathrm{FICl}$ & O877 \\
\hline Ficus laevigata & FILA & \\
\hline Ficus lutea & FILU & 7158 \\
\hline Genipa americana & GEAM & 7235 \\
\hline Grevillea robusta & GRRO & 7273 \\
\hline Guaiacum officinale & GUOF & 7279 \\
\hline Guapira fragrans & GUFR & 7285 \\
\hline Guarea guidonia & GUGU & 7290 \\
\hline Homalium racemosum & HORA & 7422 \\
\hline Hura crepitans & HUCR & 7434 \\
\hline Hymenaea courbaril & HYCO & 7442 \\
\hline Inga fagifolgia & INFA & \\
\hline Inga fastuosa & INGFA & \\
\hline Inga laurina & INLA & 7470 \\
\hline Inga vera & INVE & 7474 \\
\hline Lagerstroemia speciosa & LASP & 7533 \\
\hline Mammea americana & MAAM & 7652 \\
\hline Mangifera indica & MAIN & $\mathrm{O} 885$ \\
\hline Manilkara bidentata & $\mathrm{MABI}$ & 7662 \\
\hline Melaleuca quinquenervia & MEQU & O992 \\
\hline Melicoccus bijugatus & MEBI & 7717 \\
\hline Miconia tetrandra & MITE & 7822 \\
\hline Thespesia grandiflora & MOSP & 8786 \\
\hline Muntingia calabura & MUCL & 7867 \\
\hline Myrcia deflexa & MYDE & 7887 \\
\hline Myrcia splendens & MYSP & 7891 \\
\hline Ocotea leucoxylon & OCLE & 7994 \\
\hline Peltophorum pterocarpum & PEPT & 8121 \\
\hline Persea americana & PEAM & 7211 \\
\hline Petitia domingensis & PEDO & 8141 \\
\hline Phoebe elongata & PHEL & \\
\hline Pilocarpus racemosus & PIEL & 8171 \\
\hline Pimenta racemosa & PIRA & 8177 \\
\hline Psidium guajava & PSGU & 8356 \\
\hline Pterocarpus indicus & PTIN & 8407 \\
\hline Quararibea turbinata & QUTU & 8422 \\
\hline Roystonea borinquena & $\mathrm{ROBO}$ & 8489 \\
\hline Schefflera morototoni & SCMO & 8558 \\
\hline Schoepfia schreberi & Shsc & 8573 \\
\hline Spathodea campanulata & SPCA & 8644 \\
\hline Spondias mombin & SPMO & 8650 \\
\hline Swietenia macrophylla & SWMA & 8679 \\
\hline
\end{tabular}


Table 7 Species found in JB-BN with species codes used in the Appendix 1 NMDS ordinations and found in Appendix G of the Forest Inventory and Analysis (FIA) user guide (https://www.fia.fs.fed.us/library/database-documentation/historic/ver6/FIADB_User_ Guide_P2_6-1-1_final.pdf). For all species, SPGRPCD $=54$ and MAJGRP $=3$ (Continued)

\begin{tabular}{lll}
\hline Species & NMDS species code & Forest service species code \# \\
\hline Swietenia macrophylla $\times$ mahagoni & SWMAMA & 0940 \\
Swietenia mahagoni & SWMA & \\
Syzygium malaccense & SYMA & TAAU \\
Tabebuia aurea & TAGL & 8713 \\
Tabebuia glomerata & TAHE & 8716 \\
Tabebuia heterophylla & TARO & 7412 \\
Tabebuia rosea & Tati & 0897 \\
Hibiscus tiliaceus & TAIN & 8744 \\
Tamarindus indica & TEGR & 8750 \\
Tectona grandis & TECA & 8873 \\
Terminalia catappa & VIDI & 8931 \\
Vitex divaricate & ZAMA & \\
Zanthoxylum martinicense & TAM & \\
\hline
\end{tabular}

\section{Abbreviations}

DBH: Diameter at breast height; JB-BN: Jardín Botánico and Bosque Estatal del Nuevo Milenio Study Site; NMDS: Non-metric multi-dimensional scaling; PERMANOVA: Permutational analysis of variance

\section{Acknowledgements}

We are grateful for helpful comments on the project from Michael Grove and Courtney Richmond. Ivan Vicéns and Luis Omar Ortiz López collected 2005 field data, and 1997 data are from Despiau Batista (1997). Olga Ramos assisted with the production of our study map.

\section{Authors' contributions}

RLS contributed to the statistical analysis and writing of the manuscript. AEL contributed to the sampling plan, data collection, and writing of the manuscript. NR contributed to the analysis plan, statistical analysis, and writing of the manuscript, and is the corresponding author. The author(s) read and approved the final manuscript.

\section{Funding}

This research was conducted in cooperation with the University of Puerto Rico.

\section{Availability of data and materials}

Data will be deposited with Dryad upon acceptance of the manuscript for publication.

\section{Ethics approval and consent to participate}

This work was conducted in accordance with all applicable laws.

\section{Consent for publication}

Not applicable

\section{Competing interests}

The authors declare that they have no competing interests.

\section{Author details}

'Department of Biological Science, Rowan University, Glassboro, NJ 08028 USA. ${ }^{2}$ International Institute of Tropical Forestry, United States Department of Agriculture Forest Service, Jardín Botánico Sur, Río Piedras, PR, USA.
Received: 20 December 2019 Accepted: 4 March 2020 Published online: 30 May 2020

\section{References}

Anderson M, Walsh DCI (2013) PERMANOVA, ANOSIM, and the Mantel test in the face of heterogeneous dispersions: what null hypothesis are you testing? Ecol Monogr 83(4):557-574

Arbizu PM (2019) pairwiseAdonis: Pairwise multilevel comparison using adonis. R package version 0.3. https://github.com/pmartinezarbizu/pairwiseAdonis . Accessed 7 June 2019.

Bader MY, Ruijten JJA (2008) A topography-based model of forest cover at the alpine tree line in the tropical Andes. J Biogeogr 35(4):711-723

Barnes BV, Pregitzer KS, Spies TA, Spooner VH (1982) Ecological forest site classification. J Forestry 80(8):493-498

Barnes BV, Zak DR, Denton SR and Spurr SH. (1998) Forest ecology. 4th Edition, John Wiley \& Sons, Inc., New York.

Batista WB, Platt WJ (2003) Tree population responses to hurricane disturbance: syndromes in a South-Eastern USA old-growth forest. J Ecol 91(2):197-212

Beard KH, Vogt KA, Vogt DJ, Scatena FN, Covich AP, Sigurdardottir R, Siccama TG, Crowl TA (2005) Structural and functional responses of a subtropical forest to 10 years of hurricanes and droughts. Ecol Monogr 75(3):345-361

Bellingham PJ (1991) Landforms influence patterns of hurricane damage: evidence from Jamaican montane forests. Biotropica 23(4a):427-433

Boose ER, Foster DR, Fluet M (1994) Hurricane impacts to tropical and temperate forest landscapes. Ecol Monogr 64(4):369-400

Boose ER, Serrano MI, Foster DR (2004) Landscape and regional impacts of hurricanes in Puerto Rico. Ecol Monogr 74(2):335-352

Breugel MV, Craven D, Lai HR, Baillon M, Turner BL, Hall JS (2019) Soil nutrients and dispersal limitation shape compositional variation in secondary tropical forests across multiple scales. J Ecol 107(2):566-581

Brokaw NVL (1985) Gap-phase regeneration in a tropical forest. Ecology 66(3): 682-687

Brokaw NVL, Grear JS (1991) Forest structure before and after Hurricane Hugo at three elevations in the Luquillo Mountains, Puerto Rico. Biotropica 23(4):386392

Brubaker SC, Jones AJ, Lewis DT, Frank K (1993) Soil properties associated with landscape positions and management. Soil Sci Soc Am J 57(1):235-239

Chazdon RL, Letcher SG, Breugel MV, Martínez-Ramos M, Bongers F, Finegan B (2007) Rates of change in tree communities of secondary Neotropical forests following major disturbances. Philos Trans R Soc B Biol Sci 362(1478):273-289 
Chu T, Guo XL, Takeda K (2017) Effects of burn severity and environmental conditions on post-fire regeneration in Siberian larch forest. Forests 8(3):76

Comita LS, Thompson J, Uriarte M, Jonckheere I, Canham CD, Zimmerman JK (2010) Interactive effects of land use history and natural disturbance on seedling dynamics in a subtropical forest. Ecol Appl 20(5):1270-1284

Despiau BA (1997) Distribución de las especies arbóreas de acuerdo al gradiente en topografía en el bosque de Río Piedras, Puerto Rico, luego de 60 años de abandono agrícola. Acta Científica 11:3-20

Duckworth JC, Kent M, Ramsay PM (2000) Plant functional types: an alternative to taxonomic plant community description in biogeography? Prog Phys Geog 24(4):515-542

Emanuel K and Sobel A (2013) Response of tropical sea surface temperature, precipitation, and tropical cyclone-related variables to changes in global and. local forcing. Journal of Advances in Modeling Earth Systems 5:1-12

Enoki T, Kawaguchi H, Iwatsubo G (1997) Nutrient-uptake and nutrient-use efficiency of Pinus thunbergii Parl. along a topographical gradient of soil nutrient availability. Ecol Res 12(2):191-199

Fortin MJ, Olson RJ, Ferson S, Iverson L, Hunsaker C, Edwards H, Levine D, Butera K, Klemas V (2000) Issues related to the detection of boundaries. Landscape Ecol 15(5):453-466

Foster DR (1988) Disturbance history, community organization and vegetation dynamics of old-growth Pisgah Forest, South-Western New Hampshire, USA. J Ecol 76:105-134

Grossman DH, Bourgeron P, Busch WDN, Cleland D, Platts W, Ray GC, Robins CR, Roloff G (1999) Principles for ecological classification. In: Szari RC, Johnason NC, Sexton WT, Malk AJ (eds) Ecological Stewardship: A Common Reference for Ecosystem Management Volume II. Elsevier Science, Oxford UK

Gutiérrez del Arroyo O, Silver WL (2018) Disentangling the long-term effects of disturbance on soil biogeochemistry in a wet tropical forest ecosystem. Global Change Biol 24(4):1673-1684

Hearn SM, Healey JR, McDonald MA, Turner AJ, Wong JLG, Stewart GB (2011) The repeatability of vegetation classification and mapping. J Environ Manage 92(4):1174-1184

Heartsill Scalley T, Scatena FN, Lugo AE, Moya S, Estrada Ruiz CR (2010) Changes in structure, composition, and nutrients during 15 years of hurricane-induced succession in a subtropical wet forest in Puerto Rico. Biotropica 42:455-463

Hills GA (1961) The ecological basis for land-use planning. Research Report 46, Research Branch, Ontario Department of Lands and Forests, Maple Ontario, 204

Hogan JA, Zimmerman JK, Uriarte M, Turner BL, Thompson J (2016) Land-use history augments environment-plant community relationship strength in a Puerto Rican wet forest. J Ecol 104(5):1466-1477

Host GE, Pregitzer KS, Ramm CW, Hart JB, and Cleland DT (1987) Landformmediated differences in successional pathways among upland forest ecosystems in Northwestern Lower Michigan. Forest Science 33:(2):445-457

Hunter JC, Parker VT (1993) The disturbance regime of an old-growth forest in coastal California. J Veg Sci 4(1):19-24

Keeton WS, Franklin JF (2004) Fire-related landform associations of remnant old growth trees in the southern Washington Cascade Range. Can J Forest Res 34(11):2371-2381

Kent M, Gill WJ, Weaver RE, Armitage RP (1997) Landscape and plant community boundaries in biogeography. Prog Phys Geog 21(3):315-353

Klijn F, Udo de Haes HA (1994) A hierarchical approach to ecosystems and its implication for ecological land classification. Landscape Ecol 9(2):89-104

Little EL, Woodbury RO, Wadsworth FH (1974) Trees of Puerto Rico and the Virgin Islands, volume 2. In: USDA Forest Service, Agricultural Handbook 449. Washington DC

Lugo AE (2004) The outcome of alien tree invasions in Puerto Rico. Front Ecol Environ 2(5):265-273

Lugo AE (2008) Visible and invisible effects of hurricanes on forest ecosystems: an international review. Austral Ecol 33(4):368-398

Lugo AE, Román Nunci E, Quiñones M, Marcano Vega H, Vicéns I (2005) El bosque estatal del nuevo milenio antes y después del huracán Georges. Acta Cientifica 19(1-3):83-105

Magurran A (2004) Measuring biological diversity. Wiley-Blackwell, Oxford, UK

McKenna P, Erskine PD, Glenn V, Doley D (2019) Response of open woodland and grassland mine site rehabilitation to fire disturbance on engineered landforms. Ecol Eng 133:98-108

Molina S, Alemañy S (1997) Species codes for the trees of Puerto Rico and the U. S. Virgin Islands. USDA Southern Research Station, International Institute of Tropical Forestry, General Technical Report 122, Asheville, NC
Mollot LA, Bilby RE, Chapin DM (2008) A multivariate analysis examining the effect of landform on the distribution of riparian plant communities of Washington, USA. Commun Ecol 9(1):59-72

Nave LE, Gough CM, Perry CH, Hofmeister KL, Le Moine JM, Domke GM, Swanston CW, Nadelhoffer KJ (2017) Physiographic factors underlie rates of biomass production during succession in Great Lakes forest landscapes. Forest Ecol Manag 397:157-173

Nobre A, Cuartas L, Hodnett M, Rennó C, Rodrigues G, Silveira A, Waterloo M, Saleska S (2011) Height above the nearest drainage - a hydrologically relevant new terrain model. J Hydrol 404(1-2):13-29

Roberts RC (1942) Soil survey of Puerto Rico. USDA Series 1936, No. 8. US Printing Office, Washington DC

Scatena FN, Lugo AE (1995) Geomorphology, disturbance, and the soil and vegetation of two subtropical wet steepland watersheds of Puerto Rico. Geomorphology 13(1-4):199-213

Schimel D, Stillwell MA, Woodmansee RG (1985) Biogeochemistry of C, N, and P in a soil catena of the shortgrass steppe. Ecology 66(1):276-282

Silva-Araya WF, Santiago-Collazo FL, Gonzalez-Lopez J, Maldonado-Maldonado J (2018) Dynamic modeling of surface runoff and storm surge during hurricane and tropical storm events. Hydrology 5(1):13

Silver WL, Lugo AE, Keller M (1999) Soil oxygen availability and biogeochemistry along rainfall and topographic gradients in upland wet tropical forest soils. Biogeochemistry 44(3):301-328

Simensen T, Halvorsen R, Erikstad L (2018) Methods for landscape characterisation and mapping: a systematic review. Land Use Policy 75:557569

Sims RA, Uhlig P (1992) The current status of forest site classification in Ontario. For Chron 68(1):64-77

Sinton DS, Jones JA, Ohmann JL, Swanson FJ (2000) Windthrow disturbance, forest composition, and structure in the Bull Run basin, Oregon. Ecology 81(9):2539-2556

Tateno R, Takeda H (2003) Forest structure and tree species distribution in relation to topography-mediated heterogeneity of soil nitrogen and light at the forest floor. Ecol Res 18(5):559-571

Uriarte M, Clark JS, Zimmerman JK, Comita LS, Forero-Montaña J, Thompson J (2012) Multidimensional trade-offs in species responses to disturbance: implications for diversity in a subtropical forest. Ecology 93(1):191-205

Uriarte M, Thompson J, Zimmerman JK (2019) Hurricane Maria tripled stem breaks and doubled tree mortality relative to other major storms. Nat Commun 10:1362

White MA, Host GE (2008) Forest disturbance frequency and patch structure from pre-European settlement to present in the Mixed Forest Province of Minnesota, USA. Can J Forest Res 38(8):2212-2226

Xi W, Peet RK, Lee MT, Urban DL (2019) Hurricane disturbances, tree diversity, and succession in North Carolina Piedmont forests, USA. J Forestry Res 30(1): 219-231

Zak DR, Hairston A, Grigal DF (1991) Topographic influences on nitrogen cycling within an upland pin oak ecosystem. Forest Sci 37(1):45-53

Zimmerman JK, Everham EMI, Waide RB, Lodge DJ, Taylor CM, Brokaw NVL (1994) Response of tree species to hurricane winds in subtropical wet forests in Puerto Rico: implications for tree life histories. J Ecol 82(4):911-922

\section{Publisher's Note}

Springer Nature remains neutral with regard to jurisdictional claims in published maps and institutional affiliations. 